УДК 349.442(477)

\title{
О.О. Квасніц̧ька
}

\section{ІСТОРИЧНИЙ РОЗВИТОК ТА СТАНОВЛЕННЯ БУДІВЕЛЬНОГО ЗАКОНОДАВСТВА У ПРАВОВОМУ ДОСВ}

Сучасне вивчення правового регулювання будівельної діяльності неможливе без врахування історичного досвіду будівельного (містобудівного) законодавства, його періодизації та основних тенденцій розвитку містобудівного законодавств на конкретних історичних етапах. Протягом історичного та соціального розвитку суспільства, політичних устроїв поступово формувалось та набувало нових правових форм будівельне законодавство i, як наслідок, змінювалися напрямки його регулювання.

Враховуючи, що будівельне законодавство $€$ частиною містобудівного законодавства, у рамках даної статті через дослідження історичних етапів розвитку та сучасного стану містобудівного законодавства аналізується процес становлення та реформування безпосередньо будівельного законодавства. Розуміючи, що сфера містобудівної діяльності $€$ занадто широкою та входить до предмету регулювання адміністративного, земельного, господарського права, дослідження матиме суто господарський характер, так як будівельна діяльність, хоча й пов'язана 3 територіальним плануванням та зонуванням, що відноситься до елементів містобудівної діяльності, їі основу становлять організаційно-господарські та господарсько-виробничі правовідносини.

В юридичній літературі нормативному регулюванню будівельної діяльності присвячені статті правників господарників, цивілістів, аміністративістів, економістів (Є. Є. Клюшниченко, М. Ю. Кудрявцева, А. Н. Асаула, В. Ф. Попондопула, В. Ф. Яковлевої, Н. О. Доценко-Білоус, İ. Г. Пірожкова, В. В. Козик, В. А. Січевалюк, Н. С. Кузнецова, Н. В. Олійник та ін.), зустрічаються публікації з приводу кодифікації законодавства у сфері містобудування (ї. О. І̇зорова, І̇. М. Миронець), окремо зустрічаємо дослідження архітектурно-містобудівельного законодавства у роботах істориків та дослідження технічного характеру (Л. В. Качемцева, У. Їваночко). Такий інтерес викликаний тим, що бу- 
дівельна діяльність, окрім державного регулювання, наявності системи господарських зв'язків, включає значний масив приписів технічного регулювання.

Між тим, незважаючи на певний інтерес науковців до будівельного законодавства, слід зазначити відсутність грунтовних напрацювань, за допомогою яких можливо з'ясувати історію вітчизняного будівельного законодавства, а питання кодифікації містобудівного законодавства розглядаються без врахування існуючої правової системи в Україні, Господарського кодексу України, який у змозі врегулювати значну частину питань, пов'язаних 3 державним регулюванням, фінансуванням та здійсненням будівельної діяльності.

Отже потреба у детальному опрацюванні існуючого матеріалу, у дослідженні генезису правових норм, що регламентують відносини у сфері будівництва $€$ актуальною та необхідною для правового досвіду України.

Мета даної статті полягає у визначені періодизації розвитку будівельного законодавства, виявленні характерних ознак окремих періодів, аналізу сучасного стану будівельного законодавства та пропозицій щодо підвищення ефективності правового регулювання будівельної діяльності.

Щоб знайти тенденцію правового розвитку походження та становлення будівельного законодавства (містобудівного законодавства), завдання полягає у співставленні діючого нормативно-правового масиву з тим, який існував у минулому юридичному досвіді. Слід зазначити, що становлення будівельного (містобудівного) законодавства проходило відповідні етапи, які звісно умовно поділяються на певні періоди у зв'язку 3 тим, що в якості критерію такої періодизації стоїть поєднання історичних нарисів та нормативно-правових актів. Так розвиток будівельного законодавства характеризується наступними періодами:

- кодифікація будівельних правил за часів Київської Русі;

- будівельне законодавство за часів кріпосного права;

- дореволюційний період регулювання сфери будівництва;

- період регулювання будівельної діяльності за радянських часів;

- період становлення та реформування будівельного законодавства у незалежній Україні.

Періодизація будівельного законодавства (містобудівного законодавства) розпочинається ще за часів первісного ладу (на рівні будівництва житла). До такого висновку дозволяють дійти історичні дослідження Біскупінського городища (середина I тисячоліття до н.е.), а саме «вся внутренняя территория городища была разрезана параллельными улицами, а между ними, вплотную примыкая друг к другу торцовыми сторонами, стояли жилые дома, перекрытые общей двускатной крышей» Правильность планировки и примерное равенство домов (10×9 метров) указывают на наличие сильной управляющей власти, которой очевидно обладал глава родовой общины» [1, с. 150]. Наявність трактату Вітрувія (I тисячоліття до н.е.) [2], який є історичною пам'яткою та визначає ха- 
рактер і напрям розвитку мистецтва і творчості часів Відродження, також $€$ підтвердженням існування певної регламентації планування i будівництва.

Однак початок кодифікації будівельного законодавства пов’язують 3 Ярославом Мудрим, так як саме в XI ст. вперше в історії Київської Русі було прийнято «Будівельний статут» - перший кодифікований документ, що регламентував вимоги до здійснення будівельного процесу. Розвиток будівельного законодавства характеризується пізнанням культури античного світу і середньовічної культури Візантії унаслідок прийняття християнства та відмови від язичницьких Богів. У цей період виникають зародки цехової організації майстрів будівельної справи, розробляються правила будівництва, що знаходять своє відображення у «Будівельному статуті» й у «Руській Правді» Ярослава Мудрого (1020 p.).

За часів кріпосного права розвиток будівельного законодавства, у якості цілісної галузі, пов'язують з діяльністю Петра I [3, с. 28], хоча окремі необхідні документи містобудівного характеру датуються XVIXVII ст. Так, перші письмові свідчення стосовно існування будівельного підряду відносяться до 1574 р. і стосуються приватних підрядів, коли відносини оформлялися у вигляді підрядних грамот або записів [4, с. 164]. Нормативне закріплення відносин будівельного підряду відбулося у 1595 р. царським наказом «О заготовлении материалов для строения Смоленской крепости» [5, с. 450], яким закріплювалися спеціальні норми про договори будівельного підряду за участю держави. У подальшому більшість нормативно-правових актів, що застосовувалася до договорів підряду, до кінця ХХ ст. мали державну направленість, оскільки держава являлася однією із сторін договору будівельного підряду, а сам договір розглядався як державний контракт, необхідний для здійснення внутрішніх функцій держави.

У 1714 р. Петром I був виданий указ «О каменном строении Петербурга», яким було введено заборону на здійснення кам'яного будівництва в інших містах країни, окрім Санкт-Петербургу. У 1718 р. указом Петра I була створена Головна поліцмейстерська канцелярія, орган, за допомогою якого здійснювалося регулювання міського будівництва та благоустрою. У 1719 р. Петро I затвердив регламент Камер-колегії, яким впроваджувалося в обов'язки укладати договори підряду для державних потреб. За часів царювання Петра I з'являються перші нормативні акти про культове будівництво, головною метою яких було встановлення обов'язковості отримання дозволу на будівництво.

Правове регулювання містобудівної діяльності тих часів характеризувалося проблемами «регулярності» планування столиці, фінансуванням будівництва, художньою регламентацією; протипожежними заходами, вузькою «географічною направленістю», адже більшість нормативноправових актів мали обмежену дію у просторі (лише Санкт-Петербургом). І̇. Г. Пірожкова зазначає що «юридические механизмы обеспечения 
действия правовых новелл лежали в русле общегражданских отношений того времени, которые определялись традиционными нормативными постулатами крепостного права: для реализации своих замыслов царь часто прибегал к действиям насильственного, по сути, крепостнического характера» [3, с. 30].

У 1737 році було прийнято будівельний кодекс «Должность архитектурной экспедиции», яким передбачалась «регулярна забудова» - 3 геометричною правильністю планування, єдиними правилами і прийомами будівництва, симетричністю при забудові вулиць, співвідношенням висоти створених споруд и їх розмірів).

В подальшому регулювання будівництва відбувалося на рівні указів, так, Катерина II у 1763 р. видала указ «О сделании всем городам, их строениям и улицам специальных планов, по каждой губернии особо», відповідно до якого у країні розпочалися роботи з перепланування міст на регулярній основі. У другій половині XVIII ст. відзначено дві сфери застосування типізації - приватно-житлове та казенне будівництво. Застосовувалися типові проекти, або так звані «зразкові проекти», які затверджувалися Сенатом одночасно з планами міст.

XIX століття відносять до періоду реформування будівельного законодавства. Так, у 1811 р. були прийняті «Урочные реестры по части гражданского строительства и по военным работам» (містили вимоги щодо затрат робочої сили і кількості матеріалів на будівництво). У 1832 р. був виданий загальний нормативний збірник «Урочное положение на все общие работы, производящиеся при крепостях, государственных зданиях и гидротехнических сооружениях», який у 1869 р. було затверджено урядом.

У 1837 р. було прийнято «Строительный устав», який став частиною повного зібрання зводу законів, що регулювали будівництво, кодифікованих на той час. «Строительный устав» складався із семи розділів і двадцяти однієї глави, в яких були викладені: положення про установи для керування будівельної частини (розділ 1), про типи казенних (2 розділ), церковних (3 розділ) і громадських будинків (4 розділ), про правила побудови міст та устрою у них вулиць, площ, мостів, фабрик і приватних будинків (5-6 розділ) і селищ (7 розділ) [6, с. 227].

«Урочное положение на все общие работы, производящиеся при крепостях, государственных зданиях и гидротехнических сооружениях» 1869 р. було направлено на впровадження нової техніки, збільшення якості будівельних робіт, містило вказівки щодо вибору і іспиту матеріалів, вимоги щодо засобів безпеки під час розібрання споруд, вимоги щодо засобів безпеки при виконанні будівельних робіт, правила і норми для забудови житлових приміщень, визначалась приблизна вартість квадратного метру різних споруд, вимоги до проектів споруд і приміщень, норми затрат будівельних матеріалів, порядок виробництва будівельних робіт, вимоги до здійснення надбудов нових поверхів на існуючих спорудах та ін. Необхідно відзначити, що у той час Росія була 
єдиною країною в світі, яка мала такий нормативний акт у сфері будівництва. Урочне положення неодноразово переглядалося та проіснувало до 1930 року, до появи «Свода производственных строительных норм». Поряд зі «Строительным уставом», «Урочным положением на все общие работы, производящиеся при крепостях, государственных зданиях и гидротехнических сооружениях» діяли «Нормы проектирования и расчета несущих (преимущественно мостовых) конструкций», які були прийняті Міністерством шляхів сполучення Росії.

Період XX століття необхідно поділити на два етапи розвитку будівельного законодавства. Перші роки Радянської влади пов'язані з житловою, виробничою кризою, шо стало наслідком Першої світової війни, громадянської війни, революції 1917 року і практично повним припиненням будівельної діяльності. Основи будівельного законодавства, закладені в період проведення реформ 1837-1864 pр., за радянських часів не були збережені.

Першим документом Радянської республіки у житловій сфері був Декрет Всеросійського Центрального Виконавчого комітету 20/VIII1918 р. «Об отмене права частной собственности на недвижимость в городах». 31917 року по 1923 рік у СРСР створювалися санітарні норми устрою і утримання житла. У період НЕПу були відмінені принципи житлового розподілу, у 1922 р. було прийнято Закон «О праве надстройки», а з 1924 року Постановою ЦВК СРСР, СНК СРСР «О жилищной кооперации» був запроваджений інститут кооперативної власності у вигляді житлових товариства та приватне будівництво отримало певний розвиток. Починаючи з 1926 р. у СРСР створюється структура проектних організацій державного підпорядкування для здійснення проектування воєнних, громадських, промислових, інженерних, інфраструктурних об’єктів, виключивши можливість здійснення приватної проектної практики. Постановою ЦВК і PНК СРСР від 4 січня 1928 р. «Про житлову політику» [7] передбачалося заохочення на будівництво великих житлових будинків за рахунок приватного капіталу шляхом встановлення спеціальних пільг, перелік яких в подальшому був регламентований Постановою РНК СРСР від 17 квітня 1937 р. «Про збереження житлового фонду та поліпшення житлового господарства в містах»[8].

У 1927-1930 роках «Урочное положение на все общие работы, производящиеся при крепостях, государственных зданиях и гидротехнических сооружениях» було повністю переглянуте і була видана нова нормативна збірка — «Свод производственных строительных норм». Проте внаслідок громіздкості і складності викладу, наявності безлічі формул і використання вузькоспеціальної термінології він був мало доступним для практичного застосування [9]. Слід зазначити, що окрім регламентації порядку здійснення будівництва, вимог до матеріалів та проектування на рівні підзаконних актів вирішувалися питання фінансування капітального будівництва державних об’єктів. Однак у цей період фінан- 
сування будівництва здійснювалося виключно за рахунок державних коштів та законодавством не була передбачена можливість залучати кошти від населення будь-яким способом, у тому числі шляхом їх об'єднання, як це було впроваджено у 20-ті роки.

Метод безповоротного фінансування капітального будівництва державних підприємств промисловості, транспорту і зв'язку був встановлений Постановою ЦВК і СНК СРСР від 9 березня 1934 р. «О безвозмездном финансировании капитального строительства государственных предприятий...» [10]. Постановою СНК СРСР від 26 лютого 1938 р. «Об улучшении проектного и сметного дела и об упорядочении финансирования строительства» [11] були затверджені Правила про договори підряду на капітальне будівництво, положення яких деталізувалися інструкціями міністерств та відомств.

Даний період розвитку будівельного законодавства характеризувався значною кількістю відомчих норм і технічних умов, мало погоджених одні з одними і «засмічених» приватними рекомендаціями, практика проектування складалася хаотично, відповідальність залишалася не врегульованою.

У 1950-х роках на зміну «Урочному положенню.....»1869 р. прийшла методика розрахунку будівельних конструкцій та основним зводом нормативних документів для будівництва стали будівельні норми і правила (БНіП). Структура БНіП включала в себе: 1) будівельні матеріали, деталі і конструкції; 2) норми будівельного проектування; 3) правила проведення і приймання будівельних робіт; 4) кошторисні норми на будівельні роботи. 3 розвитком технологій, збільшенням об’ємів і потреб будівництва будівельні норми і правила переглядалися у 1962 , 1974, 1982 роках. Постановою Ради Міністрів СРСР від 24 серпня 1955 р. «Об упорядочении планирования, укреплении хозяйственного расчета, финансовой дисциплины и улучшения сметного дела в строительстве» були затверджені правила фінансування будівництва [12], які втратили свою силу 1988 р. Даною Постановою були затверджені нові Правила про договори підряду на капітальне будівництво, укладення таких договорів продовжувало здійснюватися на підставі нормативних відомчих або міжвідомчих інструктивних вказівок адміністративного характеру. У подальшому Правила переглядалися та у 1969 р. були прийняті нові Правила про договори підряду на капітальне будівництво, які значно відрізнялися від Правил 1955 р.

У 1955 році відбулася переорієнтація у житловому, громадському та промисловому будівництві: було зроблено акцент на спорудження об’єктів будівництва за типовими проектами, «без надмірностей», на основі індустріальних методів будівництва. Згідно з Постановою ЦК КПУ і Ради Міністрів від 22 вересня 1955 р. будівництво житлових, культурно-побутових будинків здійснювалося за типовими проектами, за індивідуальними - можливо було лише в окремих випадках за дозволом Держбуду УРСР. 
За дорученням Ради Міністрів СРСР Держаним комітетом Ради Міністрів СРСР у справах будівництва були затверджені норми будівельного проектування, які містили в собі правила будівельного проектування.

Постановою ЦК КП України та Ради Міністрів УРСР «Про розвиток житлового будівництва в Українській РСР» від 24 серпня 1957 р. не лише визначалися напрямки республіканської політики у сфері житлового будівництва, але передбачалося збільшення обсягів житлового будівництва за рахунок, у тому числі, коштів населення [13]. Відповідно 30 квітня 1958 року Постановою Ради Міністрів УРСР було затверджено Положення про житлово-будівельні колективи та індивідуальних забудовників у містах, селищах міського типу Української РСР [14]. Питання правового режиму джерел капітального будівництва вирішувалося за допомогою рішень Пленуму ЦК КПРС і XXIII з'їзду партії 1965 р. Так, забезпечення капітального будівництва фінансовими ресурсами здійснювалося за допомогою: коштів державного бюджету, власних коштів соціалістичних підприємств, кредитних ресурсів Будбанку i Держбанку СРСР [15].

У кінці 1980-х років у країні була сформована ієрархічна система нормативних документів, що регулювали будівельну діяльність, будівельні норми і правила (БНіП), державні стандарти на будівельні матеріали, деталі, конструкції, що містили вимоги до цих виробів промислового виробництва, стандарти Системи проектної документації для будівництва (розробленої в кінці 1970-х рр.) з вимогами до робочих проектів у сфері будівництва, санітарні норми і правила і т.д. Отже правове регулювання будівельної діяльності за часів радянського союзу у більшій частині здійснювалося на підставі нормативної та рекомендаційної бази, що включала значну кількість технічних норм.

Довгий час правове регулювання містобудування знаходилося у спільній компетенції Союзу РСР і союзних республік. Загальносоюзне правове регулювання здійснювалося за допомогою урядових і відомчих нормативних актів. Республіканське містобудівне законодавство деталізувало загальносоюзні нормативні правові акти і пристосовувало їх до місцевих умов.

Після розпаду СРСР та з проголошенням у 1991 році незалежності України, з прийняттям Конституції України пов'язаний наступний період реформування будівельного законодавства, що характеризується деталізацією, великим обсягом нормативно-правових актів, у тому числі норм технічного спрямування, складною системою законодавства, яка включає значну кількість законодавчих актів.

З прийняттям у 1992 році Закону України «Про основи містобудування», у 1999 р. - «Про архітектурну діяльність», у 2000 р. - «Про планування і забудову територій», «Про особливості приватизації об’єктів незавершеного будівництва», у 2002 р. - «Про генеральну схему планування території України», у 2005 р. - «Про порядок прий- 
няття рішень про розміщення, проектування, будівництво ядерних установок і об'єктів, призначених для поводження з радіоактивними відходами, які мають загальнодержавне значення», у 2006 р. - «Про комплексну реконструкцію кварталів (мікрорайонів) застарілого житлового фонду» був сформований новий підхід країни до будівельного законодавства, основних правових конструкцій, правового статусу учасників будівельної діяльності (коло яких було значно розширено у зв'язку з переходом до ринкових механізмів економіки), способів та порядку здійснення будівництва, засобів державного регулювання та контролю.

Закон України «Про основи містобудування»від 16 листопада 1992 р. визначив правові, економічні, соціальні та організаційні засади містобудівної діяльності в Україні, закріпив поняття та вимоги до містобудівної діяльності, визначив основні напрямки державного регулювання будівельної діяльності та компетенцію органів у сфері містобудування. Складовими містобудівної діяльності стали: прогнозування розвитку населених пунктів і територій; планування; забудова та інше використання територій; проектування; будівництво об’єктів містобудування, спорудження інших об'єктів; реконструкція історичних населених пунктів при збереженні традиційного характеру середовища; реставрація та реабілітація об’єктів культурної спадщини, створення інженерної інфраструктури; створення транспортної інфраструктури.

Постановою Кабінету Міністрів від 27 грудня 2001 р. «Про затвердження Порядку державного фінансування капітального будівництва» вперше було надано визначення поняттю «капітального будівництва», а в подальшому будівництво за державні кошти було регламентовано низкою підвідомчих актів, та на сьогодні дане питання окрім вищевказаних нормативних актів регулюється Бюджетним кодексом України, Законом України «Про здійснення державних закупівель», Законом України «Про державно-приватне партнерство», Постановою Кабінету Міністрів України «Про затвердження Порядку використання коштів, передбачених у державному бюджеті для підтримки будівництва вуглета торфодобувних підприємств і здешевлення кредитів для їх технічного переоснащення» від 2 квітня 2012 р. № 286 та ін.

Відповідно до Декрету Кабінету Міністрів України «Про стандартизацію та сертифікацію» від 10 травня 1993 р. державні будівельні норми та правила, які були у спадок прийняті від колишнього СРСР, були прирівняні до державних стандартів України та стали вагомим джерелом будівельного законодавства. На сьогодні значна увага приділяється технічному регулювання, що підтверджується прийняттям Законів України «Про стандартизацію», «Про підтвердження відповідності», «Про акредитацію органів з оцінки відповідності», «Про стандарти, технічні регламенти та процедури відповідності». Розпорядженням Кабінету Міністрів схвалена Концепція розвитку технічного регулювання та споживчої політики у 2006-2010рр., змістовна конструкція якої констатує невідповідність технічного регулювання основним положенням ЄС та вка- 
зує проблеми, які спричиняють уповільнення розвитку системи технічного регулювання.

Наряду з вищевказаними законами питання технічного регулювання будівельної діяльності регламентовано ч. 1 ст. 15 Господарського кодексу України, Законом України від 5 листопада 2009 р. «Про будівельні норми», Постановами Кабінету Міністрів України від 20 грудня 2006 р. «Про затвердження Технічного регламенту будівельних виробів, будівель і споруд»; від 1 березня 2006 р. № 240 «Про затвердження Правил підтвердження придатності нових будівельних виробів для застосування»; від 7 жовтня 2003 р. № 1585 «Про затвердження Технічного регламенту модулів оцінки відповідності та вимог щодо маркування національним знаком відповідності, які застосовуються в технічних регламентах 3 підтвердження відповідності»; Розпорядженнями Кабінету Міністрів України від 14 липня 2010 р. «Про затвердження Концепції реалізації державної політики з нормативного забезпечення будівництва в Україні на період до 2015 р.»; від 12 жовтня 2011 р. «Про затвердження Порядку застосування будівельних норм, розроблених на основі національних технологічних традицій, та будівельних норм, гармонізованих 3 нормативними документами Європейського союзу».

3 розвитком підприємницького активності питання здійснення будівельної діяльності суб'єктами господарювання та правове регулювання відносини у сфері будівництва стало вирішуватися за допомогою приписів Господарського кодексу України від 16 січня 2003 р., Законів України «Про ліцензування певних видів господарської діяльності» від 1 червня 2000 р., «Про дозвільну систему у сфері господарської діяльності» від 6 вересня 2005 р., «Про екологічну експертизу» від 9 лютого 1995 р., «Про відповідальності підприємств, їх об’єднань, установ і організацій за правопорушення у сфері містобудування» від 14 жовтня 1994 р., постанов Кабінету Міністрів України «Про ліцензування господарської діяльності, пов'язаної із створенням об'єктів архітектури» № 1396 від 5 грудня 2007 р., «Деякі питання виконання підготовчих і будівельних робіт» від 13 квітня 2011 р. № 466, «Питання прийняття в експлуатацію закінчених будівництвом об'єктів» від 13 квітня 2011 р. № 461, «Про затвердження Порядку проведення експертизи містобудівної документації» від 25 травня 2011 р. № 548, наказів Міністерства регіонального розвитку та будівництва України від 27 січня 2009 р. № 47 «Про затвердження Ліцензійних умов провадження господарської діяльності у будівництві, пов'язаної із створенням об'єктів архітектури» і т.д.

Питання фінансування та залучення грошових коштів на будівництво житла урегульовано Законами України «Про інвестиційну діяльність» від 18 вересня 1991 р., «Про фінансово-кредитні механізми і управління майном при будівництві житла та операціях з нерухомістю» від 19 червня 2003 р. Між тим, з прийняття відповідних законодавчих актів гарантованості у реалізації суб'єктивних прав учасники будівельних правовідносин не отримали. Проблеми, які існували та продовжують існувати 
у фінансуванні та залученні грошових коштів від фізичних та юридичних осіб на будівництво житла спричинили прийняття 3 березня 2006 року Указу Президента «Про заходи щодо вдосконалення державного регулювання у сфері будівництва житла та стабілізації ситуації на первинному ринку житла».

Договірні правовідносини у сфері будівництва регулюються приписами Господарського та Цивільного кодексів, Постановою Кабінету Міністрів України «Про затвердження Загальних умов укладення і виконання підряду в капітальному будівництві» від 1 серпня 2005 р. № 668, Наказом Державного комітету України з будівництва та архітектури «Про затвердження Примірного договору підряду в капітальному будівництві» від 27 жовтня 2005 р. № 3 та ін.

Порівнюючи будівельне законодавство на перших етапах незалежності України із сучасним, слід констатувати, що воно зазнало значних змін. 3 прийняттям Законів України «Про внесення змін до деяких законодавчих актів України щодо сприяння будівництву» від 16 вересня 2008 р. та «Про запобігання впливу світової фінансової кризи на розвиток будівельної галузі та житлового будівництва» від 25 грудня 2008 р. було внесено чимало змін до базових нормативних актів, регулюючих складну та обтяжливу документами дозвільного характеру процедуру капітального будівництва.

За останні роки в Україні активне проведення правової реформи зумовило прийняття десятків нормативно-правових актів і появу нових правових способів і засобів державної дії на будівельну діяльність. Неодноразово змінювалися дозвільні процедури у сфері будівництва, зазнали зміни механізми фінансування об’єктів будівництва, питання ліцензування, нагляду і контролю за веденням будівельної діяльності, правовий статус учасників цих правовідносин, процедури проведення будівельного процесу і прийняття об’єктів будівництва в експлуатацію.

18 липня 2007 року Розпорядженням Кабінет Міністрів України схвалив Концепцію Містобудівного кодексу України [16], метою якого стала систематизація норм містобудівного законодавства та вдосконалення правового забезпечення містобудівної діяльності. Проект Містобудівного кодексу України (реєстр. № 6400 від 18 травня 2010 р. внесений народним депутатом України Сербіним Ю.С.) [17] розрахований на створення сприятливих умов для подальшого розвитку містобудівної діяльності та підвищення рівня гарантій для інвестицій у будівництво, готується на друге читання Верховною Радою України.

Сучасне реформування будівельного законодавства пов'язане з прийняттям Закону України «Про регулювання містобудівної діяльності» від 17 лютого 2011 р. [18]. З ухваленням нового Закону України «Про регулювання містобудівної діяльності»втратив чинність Закон України «Про планування та забудову території» та українське співтовариство у черговий раз отримало нові «правила гри» і значну кількість змін, більш ніж у 20 інших законів, що регулюють будівельну діяльність. 
3 прийняттям Закону України «Про регулювання містобудівної діяльності» була змінена концепція реалізації будівельних проектів, зазнали змін дозвільна процедура у здійсненні будівництва, строки та порядок отримання документів дозвільного характеру, з'явився поділ об'єктів будівництва за категоріями складності та новий порядок введення об’єктів будівництва в експлуатацію.

Між тим існуючий масив нормативно-правового регулювання будівельної діяльності в Україні (навіть оновлений) залишає прогалини у визначеннях правових понять (дефініцій), відсутня цілісна державна інформаційно-правова система регулювання містобудівної діяльності, в яку входить і будівельна діяльність, а великий обсяг нормативного матеріалу не дозволяє вирішити проблем, пов'язаних із організацією та здійсненням будівельної діяльності.

Аналіз розвитку та становлення будівельного законодавства в Україні дозволяє констатувати, що українська правова система втілила в себе багато положень, які існували за часів Радянського Союзу. При цьому, враховуючи інтеграційні процеси та адаптацію національного законодавства до європейських стандартів, будівельне законодавство зазнало значних змін та потребує подальшої гармонізації. Однак ефективність правового регулювання будівельної діяльності залежатиме від наступних умов:

- наявності продуманої концепції вдосконалення системи законодавства у сфері будівництва;

- юридичної доктрини, на підставі якої буде проведена модернізація господарського законодавства і правової системи;

- дотримання меж правового регулювання;

- дотримання вимог законодавчої техніки;

- мір розробленості процесуальних механізмів дії закону.

Для ефективності, дієвості будівельного законодавства вбачається необхідність у нарощуванні нормативного змісту Господарського кодексу України за рахунок імплементації до нього норм чинних нормативноправових актів у сфері будівництва, поповнення новими нормами за рахунок скорочення кількості законів у даній сфері. При цьому, враховуючи, що будівельне законодавство $є$ безсистемним, слід розробити саме систему нормативних актів, що регулюють правовідносини суб'єктів господарювання у сфері будівельної діяльності на основі класифікацій, системи термінів і понять, побудови древа нормативних актів, перевірених правозастосовчою практикою.

\section{Л і т е р а т у р а}

1. Бунин А. В. История градостроительного искусства. Т. 1 / А. В. Бунин. - М. : Гос. изд-во лит. по строительству и архитектуре, 1953. - 530 с.

2. Витрувий. Десять книг об архитектуре / Buтрувий. - Репринт. изд. - М., 2006. -328 с. 
3. Пирожкова И. Г. Правовая регламентация градостроительства в первой четверти XVIII в. / И. Г. Пирожкова // Правовые вопросы строительства. - 2007. - № 2. - C. $28-31$.

4. Редкин П. Юридические записки. Т. 1 / П. Редкин. - М., 1841. - 465 с.

5. Акты, собранные в библиотеках и архивах Российской Империи Археологической экспедиции Императорской Академии наук. Т. 1. - СПб., 1836. - 776 с.

6. Власюк А. И. Эволюция строительного законодательства России в 1830-е - 1910-е годы / А. И. Власюк // Памятки русской архитектуры и монументального искусства: города, ансамбли, зодчие. - М. : Наука, 1985. - С. 226-246.

7. О жилищной политике : постановление ЦИК СССР, СНК СССР от 4 янв. 1928 г. // Собрание законов. - 1928. - № 6. - С. 49.

8. О сохранении жилищного фонда и улучшении жилищного хозяйства в городах: постановление ЦИК и СНК СССР от 15 окт. 1937 г. // Решение партии и правительства по хозяйственным вопросам : сб. док. - M. : Политиздат, 1967. - Т. 2 . C. 617.

9. Строительные нормы и правила - история создания [Электронный ресурс]. Режим доступа: http://spad.kiev.ua/news/1169-stroitelnye-normy-i-pravila-istoriyasozdaniya.html.

10. О безвозмездном финансировании капитального строительства государственных предприятий... : постановление ЦИК и СНК СССР от 9 марта 1934 р. // Собрание законов СССР. - 1934. - № 15. - С. 105.

11. Об улучшении проектного и сметного дела и об упорядочении финансирования строительства: постановление СНК СССР от 26 февр. 1938 г. // Собрание законов СССР. - 1938. - № 9. - С. 58.

12. Об упорядочении планирования, укреплении хозяйственного расчета, финансовой дисциплины и улучшения сметного дела в строительстве: постановление Совета Министров СССР от 24 авг. 1955 г. [Электронный ресурс]. - Режим доступа: http:/ /www.consultant.ru/online/base/?req=doc;base=ESU; $=6881$.

13. Про розвиток житлового будівництва в Українській РСР : постанова ЦК КП України і Ради Міністрів УРСР від 24 серп. 1957 р. № 988 // ЗП УРСР. - 1957. — № 12. - C. 154.

14. Про затвердження Положення про житлово-будівельні колективи та індивідуальних забудовників у містах, селищах міського типу Української РСР : постанова Ради Міністрів УРСР від 30 квіт. 1958 р. № 514 // ЗП УРСР. - 1958. - № 4. - С. 83.

15. О совершенствовании планирования и усиления экономического стимулирования промышленного производства : постановление ЦК КПСС и Совета Министров СССР от 4 окт. 1965 г. // СП СССР. - 1965. - № 19-20. - С. 153.

16. Про схвалення Концепції Містобудівного кодексу України : розпорядження Кабінету Міністрів України від 18 лип. 2007 р. № 536-р //Офіційний вісник України. — 2007. - № 53. - С. 105.

17. Містобудівний кодекс України. Проект Закону від 18.05.2010 р. [Електронний ресурс]. - Режим доступу: http://w1.cl.rada.gov.ua/pls/zweb_n/ webproc4_1?pf3511=37713.

18. Про регулювання містобудівної діяльності : Закон України від 17 лют. 2011 р. // Відомості Верховної Ради України. - 2011. - № 34. - С. 1544.

\section{А н о т а ц і я}

Квасніцька О.О. І̇сторичний розвиток та становлення будівельного законодавства у правовому досвіді України. - Стаття.

Публікацію присвячено дослідженню періодизації будівельного законодавства, генезису правових норм, що регламентують правовідносини в сфері будівництва. Проаналізовані основні етапи розвиту та сучасний стан містобудівельного законодавства, на 
підставі чого зроблені самостійні висновки та пропозицій щодо підвищення ефективності правового регулювання будівельної діяльності.

Ключові слова: будівельне законодавство, містобудівне законодавство, будівництво, будівельна діяльність, кодифікація, господарська діяльність, господарсько-правове регулювання.

\section{Ан нота ция}

Квасницкая O. А. Историческое развитие и становление строительного законодательства в правовом опыте Украины. - Стаття.

Публикация посвящена исследованию периодизации строительного законодательства, генезиса правовых норм, которые регламентируют правоотношения в сфере строительства. Проанализированы основные этапы развития и современное состояние градостроительного законодательства и, как результат, сделаны самостоятельные выводы и предложения относительно повышения эффективности правового регулирования строительной деятельности.

Ключевые слова: строительное законодательство, градостроительное законодательство, строительство, строительная деятельность, кодификация, хозяйственная деятельность, хозяйственно-правовое регулирование.

\section{S u m m a r y}

Kvasnitska $O$. O. Historical development and becoming of a build legislation is in legal experience of Ukraine. - Article.

The publication is devoted research of periodization of a build legislation, genesis of legal norms which regulate legal relationships in the field of building. An author analyzed the basic stages of development and modern state of town-planning legislation, and as a result, independent conclusions were done and suggestion in relation to the increase of efficiency of the legal adjusting of a build activity.

Keywords: build legislation, town-planning legislation, building, build activity, codification, economic activity, commercial-legal adjusting. 